\title{
Breast Cancer Clinical Regional Lymph Nodes TNM Finding v6
}

National Cancer Institute

\section{Source}

National Cancer Institute. Breast Cancer Clinical Regional Lymph Nodes TNM Finding v6. NCI Thesaurus. Code C73345.

A clinical finding about one or more characteristics of breast cancer, following the rules of the TNM AJCC v6 classification system as they pertain to staging of regional lymph nodes. 